UNIO - EU Law Journal. Vol. 3, N. 1, janeiro 2017, pp 1-2.

®2017 Centro de Estudos em Direito da União Europeia

Escola de Direito - Universidade do Minho

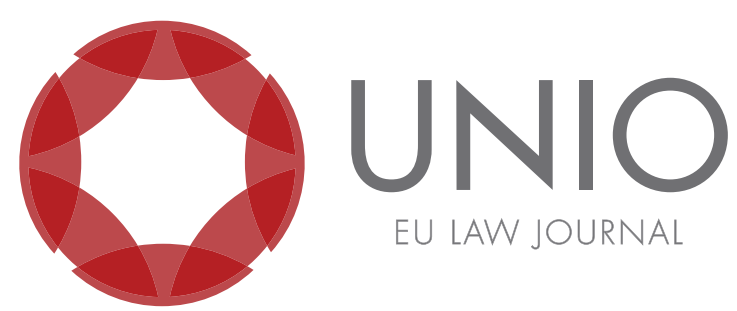

\title{
Editorial
}

Esta edição especial de UNIO - EU Law Journal celebra o 40. ${ }^{\circ}$ aniversário da Constituição da República Portuguesa (CRP) e o 30. aniversário da adesão de Portugal à União Europeia, eventos ocorridos em 2016. Para participar nas comemorações e a fim de debater ambos os eventos, o Centro de Estudos em Direito da União Europeia (CEDU) da Universidade do Minho, com o apoio do Gabinete de Informação do Parlamento Europeu em Portugal, promoveu uma conferência intitulada: "40/30: do projeto constitucional ao projeto de integraçáo - esperanças, cepticismo e realidade, num debate politico-constitucional', que teve lugar na Escola de Direito da Universidade do Minho, a 28 de outubro de 2016.

O objetivo maior da conferência e dos artigos que aqui se apresentam foi o de refletir sobre o caminho trilhado durante estes 40 anos de CRP, 30 dos quais em interação com o projeto constitucional Europeu. O que se pretendia originariamente? Foi ou não atingido? Que adaptaçoes, onde chegámos, para onde vamos? Estas perguntas foram colocadas numa perspetiva intergeracional e em diálogo entre académicos e Deputados ao Parlamento Europeu.

Abrimos este número da revista com um texto do Professor Gomes Canotilho sobre a problemática do Estado de Direito no discurso jurídico-constitucional contemporâneo. É um texto denso, cuja tradução para inglês se revelou um desafio. O autor escreve acerca dos "testes de stress" a que o Estado de Direito está hoje sujeito, designadamente, o alegado excesso de garantismo em matéria de direitos fundamentais e a sua difícil compatibilização com as ideias de eficácia e a eficiência. Em seguida, e ainda no plano da teoria constitucional, Francisco Balaguer reflete sobre o conceito de "identidade constitucional nacional", no quadro da União Europeia, sugerindo uma compreensão do mesmo que poderá facilitar a articulação entre as ordens jurídicas nacionais e a europeia.

Os textos de Wladimir Brito, Maria Lúcia Amaral e Mariana Canotilho são, ao mesmo tempo, exercícios de memória e olhares sobre o futuro. Todos partem de um ponto de vista comum, o da Constituição Portuguesa e o seu projeto político e constitucional próprio, que foi moldado, ao longo das últimas décadas, para acomodar as necessidades e exigências do projeto de integração europeia. Os autores assinalam aqueles que são, no seu entendimento, os principais sucessos e fracassos deste processo histórico e constitucional, e identificam os desafios que consideram incontornáveis num futuro próximo. 
O conjunto seguinte de artigos versa sobre um tópico fundamental: a cidadania. Alessandra Silveira e Rui Lanceiro analisam a evolução do status de cidadão europeu, em particular no que diz respeito à garantia de igual tratamento e ao gozo de direitos sociais. Tendo em mente o papel essencial do TJUE na construção da cidadania europeia e a recente evolução da jurisprudência deste Tribunal, onde nos situamos e em que direção caminhamos? O status de cidadão europeu é ainda o elo entre a União e os seus povos, conferindo proteção adicional que não deriva diretamente da cidadania nacional?

Em seguida, o trabalho de Maria José Rangel Mesquita aborda questões que decorrem do processo de integração, e da inevitável necessidade de coordenação entre o ordenamento constitucional nacional e o Europeu. A autora trata matérias como a política externa e de segurança comum, a governação económica e a salvaguarda dos valores fundamentais da União, mesmo no confronto com um Estado-Membro. O texto de Sophie Fernandes parte de uma abordagem metodológica similar - o confronto entre as ordens jurídicas nacional e da União Europeia - mas, neste caso, versando sobre a garantia de uma boa administração e sobre os direitos fundamentais com ela relacionados.

Por último, mas não menos fundamental, o artigo de Pedro Froufe tem por objeto um dos principais problemas da União Europeia, hoje: a constituição económica da União e, naturalmente, o seu projeto político e económico. O autor identifica as mudanças mais significativas nas referências ao "mercado", nos Tratados, após Lisboa; sugere também que pode haver margem para acomodar uma visão do mercado comum mais socialmente comprometida, de acordo com a matriz originária ordoliberal. $\mathrm{O}$ trabalho de Joana Abreu tem, igualmente, como tema central o mercado, mas desta vez numa dimensão mais específica, a do mercado comum digital. Este constitui um objetivo político novo e, possivelmente, um instrumento fundamental para Estados, cidadãos e empresas, no futuro.

\section{Equipa editorial}

